\title{
"Iowa's Biggest Politician"
}

Frank D. DiLeva

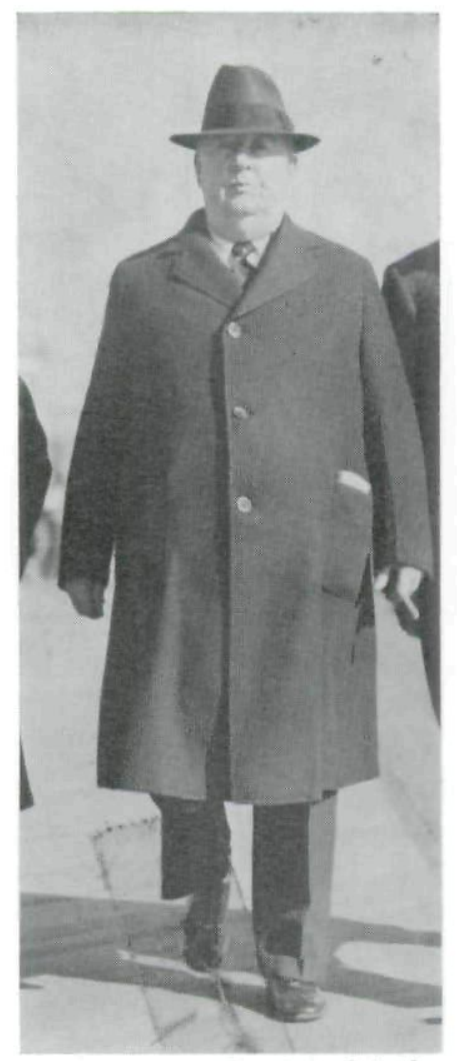

Courtesy of Autbor

Michael P. Conway

THIS IS A short summary of the life of a man who engaged in one of the most hazardous of human occupations from the standpoint of tenure: politics. As practiced in the United States at lower levels, politics often requires long apprenticeship, with little assurance of security. Michael P. Conway experienced a great deal of what local politics had to offer him. He worked within the political system, utilizing the best of his abilities and talents and tirelessly accepting the vagaries of political life.

Conway was born to Letitia Malone and Thomas F. Conway on March 22, 1877. ${ }^{1}$

Seven children were born to the elder Conways after Mike. The others, in the order of their birth, were: Mary Anne, September 1, 1878; Ellen, February 23, 1881; Letitia, January 5, 1883; Teresa Agnes, September 30, 1885; Charles Jerome, September 30, 1886; Alice Elizabeth,

${ }^{1}$ Letitia Malone was a member of a pioneer Iowa family. Her mother, Mary Malone, died at the age of eighty in Adair, Iowa, after having 
December 16, 1888; and Julia Frances, April 6, 1891. ${ }^{2}$ When Michael was fourteen his father, a Civil War Veteran, died. The son was forced to take over the operation of the family farm, located between Massena and Atlantic. In addition to farming, young Conway followed the wheat harvest into Canada, and for excitement, raced horses. ${ }^{3}$

Conway attended the local rural school for a time, then transferred to a parochial school in Creston. He went to high school at Lenox. He entered Atlantic Business School in 1892 and graduated in 1896. After graduation he worked for two years on the railroad. Later, out of an office in Atlantic, he engaged in buying and selling farm properties under the name of Conway and Smith. ${ }^{4}$ He made many trips to Minnesota, South Dakota and Canada. At one time he owned a farm in South Dakota. Most of the properties were placed in the care of tenants.

At age twenty-two Conway married Agnes Troy. The couple was married in Saints Peter and Paul Church in Atlantic on September 12, 1899. Conway's mother, a very practicallyminded woman, presented the newlyweds with a cow. Agnes and Mike Conway had four children: Rose Letitia, born August 27, 1900; Irene Josephine, born March 19, 1902; Agnes, born December 19, 1904; and Charles, born May 25, 1907.

The family lived on a farm near Anita and in 1907 moved from the farm to Atlantic because Conway had decided that he preferred real estate business to farming. His interest in politics seems to have been awakened in him early. Though a staunch Democrat, he attended the 1912 Republican conven-

been a long time resident of Lincoln Township. The marriage of Letitia Malone and Thomas Conway took place on November 21, 1875 in Winterset, Iowa.

${ }^{2}$ Information from the family bible, provided by Elaine Davey, niece of Michael Conway.

${ }^{3}$ Letter to the author from Mrs. Rose Walter, daughter of Michael Conway, March 10, 1970. Conway's sister, Alice Conway O'Brien, related as her earliest memory of her brother: "When he played an April Fool's joke on me and my sister Jule by giving us a bag filled with sticks and telling us it was candy." From a letter to the author from Mrs. Alice Conway O'Brien, August 1970.

${ }^{4}$ Personal interview with Rose Walters. Several interviews were conducted throughout June 1970 while Mrs. Walters was a guest in the author's home. 


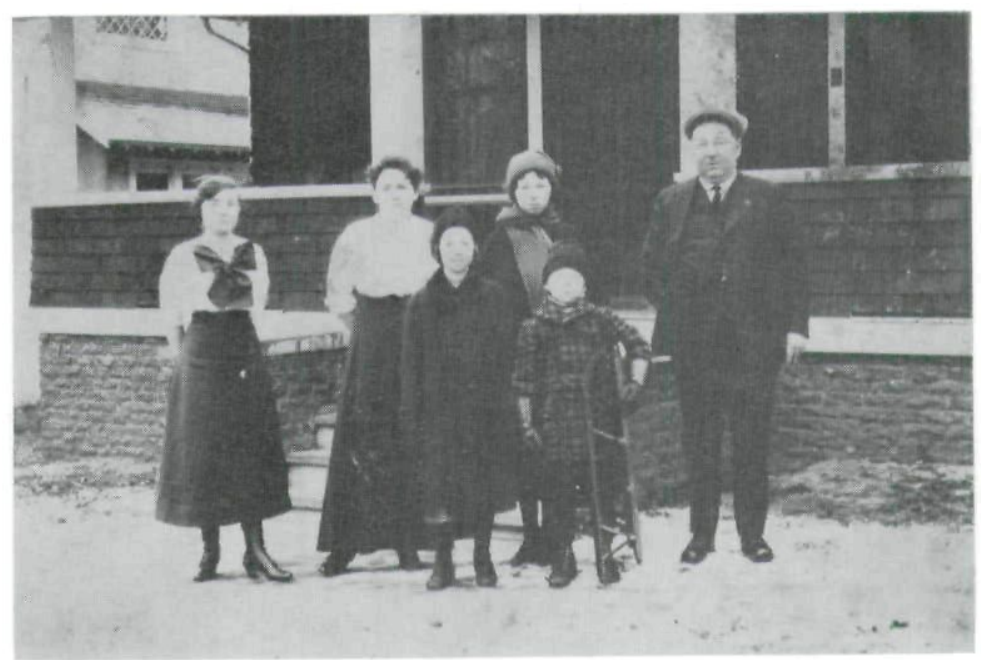

Courtesy of Autbor

Michael P. Conway (far right) and his family, circa 1915

tion, and witnessed the walk-out of the "Bull Moose Party." He placed a rather large bet on Woodrow Wilson and won $\$ 500.5$

When the U. S. entered World War I, the Cass County (Iowa) Council of Defense, chaired by Mike Conway, became a hub of "home front" war activities supportive of the home front war effort. The Council was created by Governor William L. Harding's proclamation on May 29, $1917 .{ }^{6}$ Its program included, among other things, "the searching out and investigation of instances of lukewarmness toward the prosecution of the war." It encouraged the sale of Liberty Bonds; so-called delinquent residents of the county were made to see the light and buy more bonds after persuasion by the Council. Mike Conway also served as head of a body within the Council known as the Committee of Military Affairs. A primary objective of this committee was:

the placing of feet of disloyalists in the path of true Americanism, performed in a firm yet reasonable manner [so that] a

${ }^{5}$ Ibid.

"The Cass County Committee of the Council of National Defense," Cass County in the World War, compiled and published by F. C. Beard. Atlantic, Iowa 1919, 141-143. (Photostat copies furnished by Mrs. Mary Orr, cousin of Rose Walters.) 
number of persons who had previously refused to perform their part in the various war activities were made to see the error of their ways.

The Cass County Council of Defense undertook the task of raising the amount of money assigned to the county under the Liberty Loan Plan. Preparatory to launching the loan campaign in Cass County, Conway was appointed ward and township chairman. The chairmen met, and each township and city was assessed a certain portion of the amount designated as the state's quota. The campaign was advertised, speakers sent out, and after a very intensive preparation period, the drive set in motion. Due to vigorous prosecution of the campaign, the county quota of $\$ 497,350$ was over-subscribed by $263 \%$. According to a flyer, "In only a comparatively few cases had it been necessary to use more than the ordinary appeal to get subscriptions for the amount expected."

The committee, headed by Conway, made the canvas for the fourth Liberty Loan in October, 1918. Despite the fact that the quota for the county was more than double that of the previous loan, the fourth loan was over-subscribed by 107\%. A fifth loan, "The Victory Loan," called for assisting the financing of demobilization. Again the committee did its job well.

Since the organzation and implementation of the Cass County Loan program was basically the same as a political campaign, it can be argued that Conway's political career had its origins during his participation in that program. He showed a talent for organization and persuasion-two talents which are very helpful to a political aspirant. His appointment to head the various committees mentioned above was probably influenced by the fact that a Democratic President was then in office. Conway had been elected Chairman of the Cass County Democratic Party and later was to be elected District Chairman, a position he held from 1918 until $19344^{7}$

At the close of World War I Conway was firmly established as an important Democrat in Cass County. He took a great deal of interest in local as well as national elections. In the election of 1920 the Democrats were defeated in the na-

${ }^{7}$ Interview with Rose Walters, June 1970. 
tional election and Republican Warren Harding assumed the presidency. This placed the Democratic Party in an eclipse which continued until 1932.

With the Democrats out of power, Conway turned his attention to selling insurance, and became a general agent for several insurance companies. He did not seem to put much effort into selling life insurance, however. ${ }^{8}$ His daughter, Irene, became his secretary in the insurance office. She related the following story:

Dad gave me my first job, after graduation, I was his secretary and my salary was $\$ 12$ a week. I was paid every Saturday. I wrote the check and he signed it. After a few weeks I decided to give myself a raise and made the check out for $\$ 15$. $\mathrm{He}$ wouldn't sign it as he said I was only worth $\$ 12$ and I think it is all I was worth. ${ }^{9}$

The 1920s were not the best years for the Democrats in Iowa, but Conway managed to keep his hand in politics, and, like all good party workhorses, continued to believe that the party would make a comeback. In 1922, as a Democratic District Committeeman, he supported Clyde Herring in the latter's bid for a U. S. Senate seat. Herring was unsuccessful in that election, being defeated by Smith W. Brookhart, but was elected Governor of Iowa in 1932 and U. S. Senator in 1936. In 1924 Conway was elected to the Democratic State Central Committee and by 1928 was again actively pursuing political offices for Democratic candidates. In that year he suffered a severe leg injury in an automobile accident which was to bother him for the rest of his life. (It may or may not have had a connection with the large tumor removed from his leg a year before his death.)

In 1928 the inhabitants of the farm belt in the United States were already experiencing the economic decline which was to shortly engulf the whole country. The decline had really begun in 1922 and, except for brief upswings, continued until the late 1930s. ${ }^{10}$ During the Depression years Conway, along

${ }^{8}$ Ibid. He did sell his daughter Rose a policy with Occidental Life of California.

${ }^{9}$ Letter to the author from Irene Conway Woolsey, October 21, 1970.

${ }^{10}$ See Frank D. DiLeva, "Frantic Farmers Fight Law," Annals of Iowa (October 1953), Vol. 32, No. 2, 81-109. 
with many others, experienced irreparable economic losses. He lost most of his land and a great deal of money, ultimately suffering the ignominious fate of seeing some of his properties foreclosed. ${ }^{11}$ Though not an uncommon occurrence during this period, it was never a welcome one.

As the Depression deepened and the ill effects of the 1929 stock market crash enveloped the lives of almost everyone, the Republican Party found itself, as might be expected in times of such crises, on the defensive. Herbert Hoover fought a bitter and acrimonious campaign against Franklin Roosevelt and, after all the political smoke had died away, the Democrats in Iowa discovered they had elected a complete slate of candidates to office. The Democratic Party majority in that election swept many into office. One of these was Mike Conway, elected Railroad Commissioner.

Conway's fondest dream of one day being elected to public office had come true. Railroad Commissioners were elected to serve four-year terms, but elections were staggered so that the three-member Commission was composed of a rotating group of office-holders. In 1934, two more Democrats, Ceorge Huffman and Harry Dunlap, were elected. During the Commission's first meeting in 1935, Mike Conway was selected Chairman. The three Democrats subsequently found themselves competing against one another for the authority to appoint other Democrats to various positions under the Commission's jurisdiction.

Of Conway's position as Chairman, the Journal Herald of Avoca (January 10, 1935) remarked-with a slight dig at his well known corpulence-that Conway was capable of filling the chair in more ways than one. Whenever news around the statehouse was too dull or too small to fill the required space, newsmen often resorted to printing a picture of Conway on a scale, accompanying an article detailing his current diet. The press consistently made much of his weight problem. It proved to be a seemingly never ending source of news, and one which Conway took with the same good natured spirit that he showed throughout his political career. In fact, his

\footnotetext{
${ }^{11}$ Letter to the author from Rose Walters, August 20, 1970.
} 
being dubbed "Iowa's Biggest Politician" was due to his girth -at one time he weighed 336 pounds. ${ }^{12}$

The Democrat-dominated Railroad Commission of the middle thirties was beseiged by a stream of applicants for jobs which far exceeded the supply. The Democrats were making it plain that they intended to clean out the Republicans who had held positions for many years. In one particular case, George D. McCaughan had been with the Commission twentyfive years but did not expect to be a candidate for reappointment as its executive secretary. ${ }^{13}$ In early 1935 the Railroad Commission found itself with 2,000 applicants for approximately sixty positions. Selection was an almost impossible task. In this era, patronage was important and had to be paid. Conway announced that employees were to be selected on a trial basis. After an initial twenty were appointed, he said, additional temporary appointments were to be made. ${ }^{14}$

Shortly after the opening of the new legislative session, Governor Clyde L. Herring indicated that he favored a socalled "Port of Entry" bill. This particular bill fell under the jurisdiction of the Railroad Commission. The Port of Entry laws which existed in other states, primarily in Kansas, were designed to make a check on out-of-state trucks moving through a state. In actual fact most of these laws were designed to extract from out-of-state truckers the ton-mile fee that was charged intrastate truckers; thus, in reality laws of this kind were really revenue raising measures. Kansas had adopted such a law, and Conway, Huffman and Dunlap visited Topeka to observe the law in operation. It is significant to note that on their return they mentioned that Kansas had reported a gain of $\$ 127,000$ in bus and truck fees during the first year of operation. ${ }^{15}$

\footnotetext{
${ }^{12}$ Conway's maximum weight is subject to dispute. The above figure is a consensus derived from weights listed in various newspapers, and those given by family members. Everyone seems to agree that he weighed more than 335 pounds.

${ }^{13}$ Atlantic News-Tribune, January 8, 1935.

${ }^{14}$ Ibid.

${ }^{15}$ Mason City Globe-Gazette, January 18, 1935. This lends credence to the supposition that the law was really a revenue device rather than a truck-control device, Not everyone favored such a law. The out-ofstate trucking firms naturally were opposed to it. The major argument
} 
The Iowa Truckers Association soon began to have qualms concerning the Port of Entry bill, and the Sioux City Chamber of Commerce held a meeting to discuss it. ${ }^{16}$ The meeting turned into a protest session, with the major arguments against the bill expressing the feeling that it would raise the cost of operating a fleet of trucks or an individual truck. A public hearing held by the legislature heard a Mr. Homer Hoch, Chairman of the Kansas Corporation Commission, discuss how Kansas had recently collected $\$ 3,300$ in deficiency mileage taxes from one truck operator. Opposition grew more vocal and the newspapers began to give the bill negative publicity. The State Railroad Commission, while continuing with the business of attempting to regulate railroads, buses and trucks, nevertheless pushed vigorously for acceptance of the bill. Its efforts proved in vain. For weeks it had seemed that the bill would surely pass, but more and more opposition to the resulting tax finally swung the vote against it. On April 11, 1935 the Iowa Senate voted it down twenty-two to twenty-five. ${ }^{17}$ While the hearings were being conducted on the Port of Entry bill, Conway and his colleagues made many speeches around the state in its support. He, especially, had worked hard because he felt the bill was badly needed.

Other problems dealt with by the Commissioners were the abandonment of the narrow gauge railroad track and the appointment of an executive secretary to the Commission, as well as a Commerce Council. It also had to examine and prepare recommendations on the many bills brought before the Iowa legislature pertaining to railroads, trucking regulations, bus regulations and various right-of-way questions. In each case Conway worked for what he considered was most bene-

against it seems to have been that it divided the U. S. into forty-eight separate entities, much like the countries of Europe and forced everyone to be inspected while in the process of crossing state borders.

The arguments opposing the bill undoubtedly should be considered as reasonable as those favoring it; nevertheless, the thought of raising revenue by charging some "outsider" was very appealing to the politicians. The bill did not receive the editorial opposition that one would expect from such a radical departure from the norm.

${ }^{16}$ Sioux City Journal, March 15, 1935.

${ }^{17}$ Des Moines Register, April 12, 1935. 
ficial to the state as a whole.

One particular aspect of the Commissioners' duties which was of interest to Conway pertained to railroad safety. He threw all of his 300 plus pounds into the job of improving safety at rail-motor vehicle crossings. A new kind of barrier was demonstrated April 21, 1935 in Des Moines on East Euclid Street at a Northwestern Railroad track crossing. The barrier rose from the roadway as a train approached an intersection and when depressed by the front wheels of the automobile, would rise nine and a half inches from the ground and forcibly prevent an automobile from crossing the tracks until the train had passed. This device caused damage, in most instances, to cars attempting to drive over it. The manufacturer, of course, maintained that this was the only possible way to stop a reckless driver. Though there may have been some merit in the device, it was apparently not widely adopted. Despite a favorable attitude on the part of the governor and Commissioners, the public was unwilling to accept potential damage to automobiles as a price for safer railroad crossings.

Throughout the legislative session of 1935, Conway continued to adopt one or another of his periodic diets. In the space of six months and twenty-six days he lost more than 100 pounds. His weight dropped from 336 to 215 pounds once he limited himself to 1500 calories per day and began walking a mile after every meal. ${ }^{18} \mathrm{He}$ took care to embark on diets only under his physician's supervision.

Following the legislative session, Conway went out and talked to the people. At Shenandoah, Iowa on September 2, 1935, he decried the defeat of his proposed trucking bill before a gathering of southwestern Iowa truckers, and predicted that one would be passed in the forthcoming legislature. He spoke wherever he was invited, attended many party gatherings, and tried to be in places advantageous to an aspiring politician. He continued, too, to battle his weight problem, gaining and losing in a fairly consistent pattern.

On January 14, 1936, according to the Atlantic News Telegraph, Conway applied for the position of Postmaster of Atlan-

\footnotetext{
${ }^{18}$ Letter from Rose Walters, August 20, 1970.
} 
tic. His daughter, Mrs. Rose L. Walters, also applied for the job. ${ }^{19} \mathrm{He}$ failed to obtain the appointment, and it is not clear what his reasons were for applying in the first place. He was re-elected chairman of the Railroad Commission for the year 1936. At that time he announced the procedure to be used by interstate truckers for the purchase of licenses in Iowa. The licenses could be bought in Mason City between January 27 and $30 .^{20}$ The state licensing of interstate truckers was the result of a change in the Interstate Commerce Act. This served the same purpose as the Port of Entry bill in that it allowed the states to regulate trucking by the use of licenses, and of course sales of the licenses produced revenue.

With the expiration date of his term as a Railroad Commissioner eleven months away, Conway announced on January 22, 1936 that he would be a candidate for re-election. The other Commissioners were holdovers; their terms would not expire until December 31, 1938. His decision to run again, Conway offered, was due to the insistence of shippers and traffic men throughout the state. He stated, "I will make the campaign on my record., ${ }^{21}$

The Railroad Commission was charged with regulating railroad rates, railroad safety, motor truck traffic, rural electrification, and electrical transmission lines, as well as air traffic and rates for aircraft service. The Commission employed twenty-six state inspectors and seventy-four office personnel. ${ }^{22}$ Eighty thousand trucks operated through or in Iowa, with different rate fee structures for intrastate and interstate traffic. The truck traffic, combined with railroad traffic and the tremendous increase in electrical transmission lines brought about by the Rural Electrification Program, made the Railroad Commission one of the busiest agencies in the state. It had become a very important regulatory agency of state government and was in need of a name more accurately descriptive of its diverse functions. Throughout 1936 a number of people spoke out in favor of a name change for the Commission.

\footnotetext{
${ }^{19}$ Atlantic News-Telegraph, January 16, 1936.

${ }^{20}$ Mason City Globe-Gazette, January 14, 1936.

${ }^{21}$ Des Moines Register, January 22, 1936.

${ }^{22}$ Atlantic News Telegraph, January 25, 1936.
} 
Conway was quoted in the Waukon Democrat (February 5, 1936) as follows:

It would seem the title Board of Railroad Commissioners should be changed to a more appropriate one since the duties of the Board are the regulation of a different number of different ways of transportation ... it would seem that some other title would be more appropriate.

Conway virtually blanketed the state during his primary campaign, and in June 1936 won the Democratic nomination for Railroad Commissioner. His opponent in the November election was George McCaughan of Ankeny, a friendly political opponent of long standing. Election day resulted in an overwhelming national Democratic victory. The national candidate for president, Franklin D. Roosevelt, carried all but two states.

Conway's battle to change the name of the Railroad Commission bore fruit in 1937 . The new name proved to be more indicative of the expanded functions of that agency: the State Commerce Commission.

During his career he made only one move toward attaining national office. According to the Atlantic News Telegraph (February 28, 1938), Conway talked of running for Congress in the Seventh Congressional District, provided that Otha Wearin, the Democratic incumbent, decided to run for the Senate. Wearin, however, decided against the Senate race and Conway did not choose to challenge him for the Congressional seat.

The election of 1938 saw two Republicans gain offices in the Commerce Commission. The new men were Barr Keshlear of Shenandoah and B. M. Richardson of Cedar Rapids. Conway found himself the "lone Democrat" on the Commission. George McCaughan, who had been defeated by Conway in 1936, was appointed Secretary of the Commission. Conway then held the distinction of being the only Democrat holding a major office in the state house after the 1938 elections.

Publicity tended to focus on the majority members; therefore, in order to attract publicity, Conway and the newspapers fell back on the old stand-by-they discussed his weight. After losing 123 pounds in 1934, his weight had climbed back to 285 pounds by 1939. His own comment on the problem was, "When 
your waistline interferes with the action of your automobile's steering wheel, it is time to call a halt." ${ }^{{ }^{23}}$ His goal was to lose eighty-five pounds by April Fool's Day, 1940; since he was starting in October, 1939, it would mean a loss of approximately fourteen pounds a month. Again Conway posed for the pictures and took all of the good-natured ribbing in his normal high humor. He did not immediately rush into some sort of crash diet, but using the same principle that had worked before, and under medical supervision, he gradually reduced his caloric intake. He interrupted his diet after fifty-three days to partake in the traditional Thanksgiving Day feast. ${ }^{24} \mathrm{He}$ had lost ten pounds by that time.

A Republican-dominated Commission reduced Conway's patronage power. This writer does not feel that the power of patronage precludes a politician from being an unselfish government servant. It is a political axiom that an office-holder can work better with those he chooses, rather than with those that have been foisted upon him. Conway seemed to work well with the opposition members, however, and by 1940 had decided that he would make a try for a third term. He had fourteen opponents in the primary, eleven Republicans and three Democrats.

Newspapers in 1940 were filled with such items as the railroads coming out of the red, erection of new crossing signals, new trucking arrangements with other states, and, along with business as usual, the undercurrent of the primary campaign. Conway won the nomination in June but the following November proved to be his personal "Waterloo." He was defeated for re-election. Conway tried again in 1942 but failed. $^{25}$ It was to be his last try for elective office. Failing health and the death of his wife prevented him from continuing his political career. His wife died on November 19, 1941. At the time, Conway was working in a defense plant in Ankeny. He later became manager of a Truck Operators' Joint Information Service, which proved to be an influential position because of the war that was in progress.

${ }^{23}$ Des Moines Register, October 8, 1939.

${ }^{24}$ Des Moines Register, November 23, 1939.

${ }^{25}$ Des Moines Register, June 7, 1943. 
In 1942 Conway had a nonmalignant tumor removed from his leg. Later he was hospitalized with a liver ailment which was not thought to be serious at first, but was found to be cancerous and inoperable. He died on June 6, 1943. Conway's last years were, unfortunately, beset with medical problems.

The newspapers in Iowa often portrayed Conway as a caricature of a politician. Paradoxically the real esteem in which he was held became apparent only after his death. In death, those whom he had befriended, and there were many from both parties, paid tribute to his going and made it perhaps one of the most memorable events ever seen in Atlantic, Iowa.

At a requiem high mass in Saints Peter and Paul Catholic Church, celebrated by Reverend P. M. McDermott of Atlantic and assisted by Reverend F. J. O'Connell of Des Moines and Reverend Peter O'Leary of Greenfield, Conway was given his last tribute on earth. ${ }^{26}$ The guest register has 121 names in it, excluding relatives. Many of the people attending the service were unable to sign the register. The cards and letters of condolences ran into the hundreds. The Atlantic News Telegraph of June 9, 1943 led off its obituary with the following:

Democratic and republican (sic) leaders and personal friends from all parts of the state filled SS. Peter and Paul's Catholic church here this morning for final rites for M. P. (Mike) Conway.

Motor Truck News (June 1943) commented:

In the preceding issue of Motor Truck News, we announced the appointment of M. P. (Mike) Conway as manager of the Des Moines Joint Information Office. Now we must chronicle his death which occurred in Des Moines, June 6th.

That $\mathrm{Mr}$. Conway should have died in a position of service to the truckers of Iowa is symbolic, for Mike's outstanding contribution as a Commerce Commissioner was his willingness to help the other fellow. Many an Iowa Trucker received help on his problems by sitting down with Mike for a "talk." The helpfulness often extended to questions beyond official commission problems and was given as freely to the one-truck operator as to the fleet owner.

This attitude can best be expressed in Mike's own words. . . "I hope the truckers will feel free to come and discuss their troubles. I want to help in any and everyway I can and sitting down face to face is the best way to get at those problems."

${ }^{26}$ Memoriam Book for Conway's funeral. 
Conway's political opposition showed respect for their fellow politician. A great many Republicans attended his funeral in Atlantic and a great many more wrote letters of condolences to the family. The list of political figures is simply too long to warrant inclusion, but among those Republicans attending was George L. McCaughan, who was defeated by Conway for the position of Railroad Commissioner. Congressman Tom Martin, a Republican, wrote a letter to the family on June 10, 1943 expressing condolences and respect for the departed Conway. ${ }^{27}$ Probably the most notable tribute came from E. P. Chase, Pulitzer Prize winner, former Editor of the Atlantic News-Telegraph and a Washington correspondent at the time of Conway's death. Writing from the nation's Capital in the June 17, 1943 issue of the Atlantic News Telegraph, he eulogized:

I regretted to learn of the death of my old friend Mike Conway. Mike was a Cass County product and was always loyal to his home county. He was a Democrat of Democrats and kept the banner aloft during the long and lean years when being a Democrat in Iowa was not exactly the most profitable occupation in the world. . .

In the years since the Republicans captured the State, Mike tried unsuccessfully to secure a position commensurate with the service he had given his party. But the Democratic "big shots" were looking out the window and good old Mike found that not only republics, but political parties are sometimes ungrateful. At the time of his death he was employed by a trucking service concern, operated by a Republican who had not forgotten that Mike, though a Democrat, kept him in a job with the Commerce Commission when there were hardly enough Republicans around the statehouse to count.

Mike because of his size, was a familiar figure around the state and got considerable newspaper publicity when he went on a diet with the object of losing more than 100 pounds. . . Mike never resented the publicity he received, was a good friend of the newspaper men and everyone else with whom he came in contact. I guess, when the score is tallied, the record of a fellow like Mike Conway will be found to add up pretty much to the good. He never became famous or wealthy and perhaps by the measuring stick most men apply he was not a great success, for he spent his life doing what the late Teddy Roosevelt said made for a full life, doing the best with what

${ }^{27}$ This letter is presently in the author's possession. Congressman Martin became Senator Martin, then retired. He died in Seattle, Washington in the Spring of 1971 . 
he had, where he was.

Conway's political life played its small drama on an equally small stage. He was purely a state politician, though receiving some notice at the national level during conventions and other political gatherings. The job he performed as Commerce Commissioner helped make that body an effective regulator of state commerce. He pushed railroad safety, licensing procedures for truckers, and produced a useable rate schedule from the morass existing previous to his tenure on the Commission. The outstanding quality he possessed was his ability to make friends and to project himself as a warm and open individual to his own party as well as to the opposition. It was definitely clear at the time of his death that he had managed to make friends on both sides of the political aisle. For that, and for being "Iowa's Biggest Politician," Mike Conway is remembered.

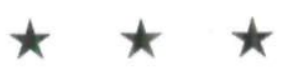

Charles Atherton Cumming, Iowa's Pioneer ArtistEducator, by Bess Ferguson with Velma Wallace Rayness and Edna Patzig Gouwens (published by the Iowa Art Guild, 1972) is a comprehensive account of Cumming's education, his work as artist-educator, his teaching, his paintings, his community work, and his personality and influence. He was born in 1858 on the Spoon River, Knox County, Illinois. He attended Cornell College, and later studied at the Art Institute of Chicago and the Academie Julien in Paris. He later embarked on what proved to be a successful teaching career. Many fine reproductions of Cumming's work are included in this biography.-Ed. 
Copyright of Annals of Iowa is the property of State of Iowa, by \& through the State Historical Society of Iowa and its content may not be copied or emailed to multiple sites or posted to a listserv without the copyright holder's express written permission. However, users may print, download, or email articles for individual use. 